(C) 1985 ISIJ

\title{
高炉スラグと溶銑中の酸素分圧の連続測定
}

技術報告

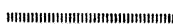

\author{
永田 和宏* ·槌谷 暢男*2 $\cdot$ 浦田 邦芳*3 \\ 松岡 正雄 ${ }^{* 3} \cdot$ 後藤 和弘 ${ }^{* 4}$
}

\section{Continuous Measurement of Oxygen Pressures in Molten Slag and Pig Iron of Blast Furnaces}

\author{
Kazuhiro Nagata, Nobuo Tsuchrya, Kuniyoshi Urata, \\ Masao MAtsuoKa and Kazuhiro S. Goto
}

\begin{abstract}
Synopsis :
Oxygen sensors have been newly designed and tested for continuous measurements of oxygen potentials in pig iron and slag at blast furnaces in operation. The key points of constructions of the sensors are that 1) one-end closed tube of $\mathrm{ZrO}_{2} .9 \mathrm{~mol} \% \mathrm{MgO}$ is used as a solid electrolyte, 2) graphite tube is used as a mount of the electrolyte and also 3 ) as an electrode in contact with pig iron, and 4) air-Pt electrode is used as a reference electrode. The sensors were tested in the runner at the skimmer of the blast furnaces. Oxygen potentials have been reliably measured for 157 min during 3 taps for pig iron and 78 min for slag in maximum.
\end{abstract}

\section{1. はじめに}

ジルコニア系固体酸化物を電解質に用いた酸素センサ 一は，溶鋼中の酸素濃度を電池の起電力から迅速に決定 できる，そのため，転炉出鋼後の脱酸工程や成分調整， 連続鋳造機のタンディッシュ中の溶鋼の酸素濃度調整に 多数用いられている. 1982 年 1 年間で約 32 万本の消 耗型酸素センサーが使われ，な技年間 6 万本の割合で伸 びている1)。製銑現場では，まだオンラインで使われて いないが，溶銑樋での脱珪処理 ${ }^{2)}$ では脱珪剤調整に溶銑 中の酸素濃度の迅速な測定が 重要になろら。また，羽 口からの石灰石吹き込みや酸化鉄吹き込みによる低シリ コン操業3), さらに溶融還元炉では, 溶銑やスラグ中の 酸素分圧と温度が反応を制御する上で重要な因子となろ う. 著者らは前報4)で, 消耗型酸素センサーにより溶銑 とスラグ中の $P_{\mathrm{O}_{2}}$ を測定し, 高炉内反応との関係を報告 した. 前回の研究では 1 回の出銑に 10 数本の消耗型七 ンサーが用いられたが，個々のセンサーによるばらつき を防ぐためには 1 本のセンサーで連続的に測定する方が 望ましいままた現場でモニターに使ら場合，コストの点 です有利である.

本研究では, 長時間測定が可能な「長寿命酸素センサ
一」を開発し，高炉操業現場で溶銑と溶融スラグ中の酸 素分圧を連続して測定した.

\section{2. 長寿命酸素センサーの問題点}

溶鉄中の酸素濃度の連続測定の研究は, 1968 年頃から 実験室的規模で, 1973 年からは実操業で始むつた ${ }^{5)}$. これらは転炉で銑鉄装入から出鋼すでの酸素濃度をモ二 ターした研究である. 実験室的規模の実験ではいずれも 炉底あるいは炉壁に 固体電解質を埋め込んである。一 方, 実操業の精錬炉を用いた研究ではセンサーを炉壁に 固定せず溶鋼に独立に插入する方式がほとんどである. これは取り扱いを簡便にするためである.

これらの研究によると長寿命センサーには次の問題点 があることがわかる．1）固体電解質とその支持材のス ラグに対する耐食性，2）標準極物質の安定性，3）固 体電解質中の部分電子伝導性や気孔を通しての酸素ガス の漏れ，4）高炉湯道中の溶銑やスラグの強い流れに耐 え得る機械的強度が固体電解質やとの支持材にあること である・

\section{3. 長寿命酸素センサーの試作}

Fig. 1 に長寿命酸素センサーの構造図を示す. それ 昭和 59 年 4 月本会講演大会飞て発表 昭和 59 年 3 月 6 日受付 (Received Mar. 6, 1984)

* 東京工業大学工学部 工博 (Faculty of Engineering, Tokyo Institute of Technology, 2-12-1 Ookayama Meguro-ku 152)

*2 川崎製鉄 (株) 技術研究所工博 (Kawasaki Steel Corp., Research Laboratories)

*3 山里エレクトロナイト(株) (Yamari-Electronite Co., Ltd.)

*4 東京工業大学工学部 Ph. D., 工博 (Faculty of Engineering, Tokyo Institute of Technology) 


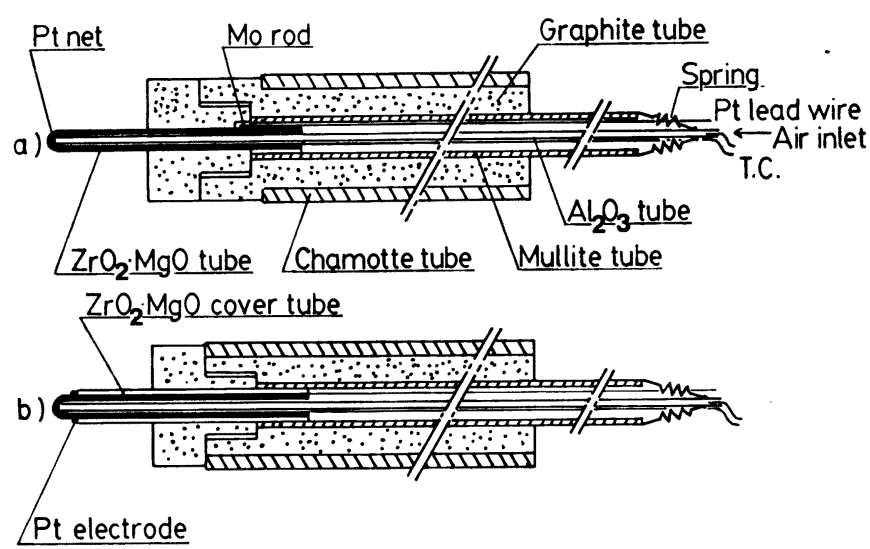

Fig. 1. Constructions of long-life sensors for pig iron (a) and slag (b).

ぞれ a）溶銑用と b) スラグ用である. 構造の要点を 次に記す.

1) 固体電解質にち密な $\mathrm{ZrO}_{2} \cdot 9 \mathrm{~mol} \% \mathrm{MgO}$ 焼結体 一端閉管を用いる. その大きさは外径 $8 \mathrm{~mm}$, 内径 5 $\mathrm{mm}$, 長さ $100 \mathrm{~mm}$ である.

2）支持材に外径 $40 \mathrm{~mm}$ ，長さ $300 \mathrm{~mm}$ の黒鉛管を 用いる，黒鉛管はシャモット管で覆い，熱風による燃焼 を防ぐ.

3 ）標準極には空気一白金極を用いる.

$4 ）$ 溶銑との電気的接触には黒鉛管を用いる.

この他，黒鉛管と白金のリード線との接続部にモリブ デン棒を埋め込み，白金が劣化するのを防止した。

スラグ用センサーでは固体電解質の 先端に 直径 0.5 $\mathrm{mm}$ の白金線を 2 回巻きスラグ側電極とした. その白金 リード線が粒鉄の付着により断線するのを防ぐため，外 径 $13 \mathrm{~mm}$, 内径 $9 \mathrm{~mm}$ の $\mathrm{ZrO}_{2} \cdot 9 \mathrm{~mol} \% \mathrm{MgO}$ 管を一 端閉管の外側に被せ，管壁のすきまに白金リード線を通 した。

空気吹き込み用アルミナ管の先端には白金網を付け， 電解質の内側にバネで押し付けた．白金網には Pt-Pt13 $\% \mathrm{Rh}$ 熱電対を溶接し，白金側を標準極のリード線に共 用した.アルミナ管の大ささは外径 $4 \mathrm{~mm}$, 内径 $2 \mathrm{~mm}$ で，その先端から約 $10 \mathrm{~mm}$ の壁に孔を開け空気の流出

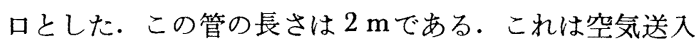
用ゴム管が溶銑やスラグの輻射熱で然焼するのを防ぐた めである.

電池の構造式は溶銑用センサーとスラグ用センサーで それぞれ次のよらになつている.

白金 $\mid$ 黒鉛 $\mid$ 溶銑 $\left(\mathrm{O}_{2}\right)$ |固体電解質, $\mathrm{O}^{2}-\mid$ 空気, 白金

白金, スラグ $\left(\mathrm{O}_{2}\right)$ |固体電解質, $\mathrm{O}^{2}$ - 空気, 白金
ここで $\left(\mathrm{O}_{2}\right)$ は溶銑あるいはスラグ中に溶解している酸 素を意味する.

これらの電池の起電力は両極の $P_{\mathrm{O}_{2}}$ と温度により決ま るが，溶銑の $P_{\mathrm{O}_{2}}$ は $10^{-14} \mathrm{~atm}$ 程度であり,このよう な低い $P_{\mathrm{O}_{2}}$ を測定する場合は固体電解質中の部分電子伝 導の寄与を考慮しなければならない，それを考慮した式 を次に示す6).

$$
P_{\mathrm{O}_{2}}=\left[\left(P_{e}^{1 / 4}+P_{\mathrm{O}_{2} \text {, ref }}^{1 / 4}\right) \exp (E F / R T)-P_{e}^{1 / 4}\right]^{4}
$$

ここで $E$ は電池の起電力 $(\mathrm{V}), F$ はファラデー定数, $R$ はガス定数， $T$ は絶対温度である. $P_{\mathrm{O}_{2}}$, ref は標準極の $P_{\mathrm{O}_{2}}$ で $0.21 \mathrm{~atm}$ である. $P_{e}$ は部分電子伝導度パラメ ータ7)で

$$
P_{e}=\exp (-171300 / T+56.23)
$$

で表される.（3)式はスラグ中の $P_{\mathrm{O}_{2}}$ の計算にも用い た.

\section{4. $50 \mathrm{~kg}$ 溶解炉での長時間測定}

$50 \mathrm{~kg}$ 高周波溶解炉を用いて 高炉から採取した 銑鉄 $35 \mathrm{~kg}$ とスラグ $2.6 \mathrm{~kg}$ を溶解し, 長寿命酸素センサー による $P_{\mathrm{O}_{2}}$ の連続測定を行つた. まず銑鉄を溶解し, 溶 銑用センサーを約 $80 \mathrm{~mm}$ 浸漬して固定した. 空気巻き 込みによる溶銑の酸化を防止するため黒鉛粒を随時添加 した. $220 \mathrm{~min}$ 後にスラグを添加溶融し，スラグ用セン サーを約 $20 \mathrm{~mm}$ 浸漬して固定した.

両方のセンサーの起電力と温度を自動電圧記録計で記 録した．測定中，消耗型酸素センサーを用いて溶銑とス ラグ中の $P_{\mathrm{O}_{2}}$ を，それぞれスラグの添加直前と実験終了 の $30 \mathrm{~min}$ 前に測定し, これらを長寿命酸素センサーの 結果と比較した。

Fig. 2 に溶銑用とスラグ用長寿命酸素センサーで測 定した電池の起電力と温度の連続測定結果を示す. 温度 は溶銑で $1450^{\circ} \mathrm{C}$ から $1600^{\circ} \mathrm{C}$ の間で変化させたが, 


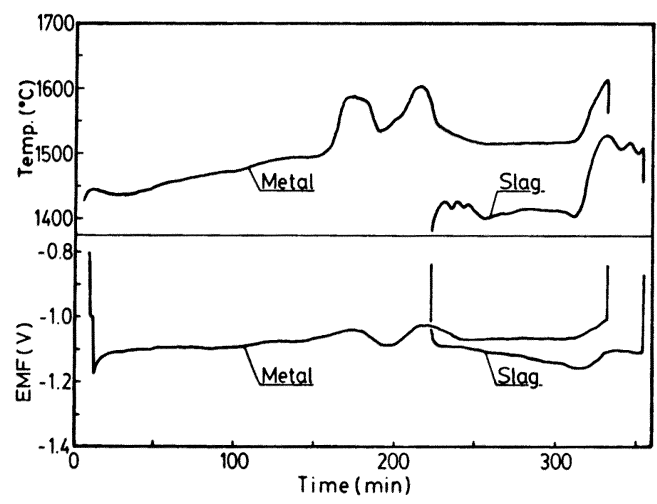

Fig. 2. Changes of E.M.F. and temperatures in pig iron and slag using $50 \mathrm{~kg}$ induction furnace.

起電力は温度の変化によく対応した． スラグは温度が最 初 $1400^{\circ} \mathrm{C}$ 程度だつたので焼結状態であつた. その後 $1500^{\circ} \mathrm{C}$ に昇温し溶融状態とした. $P_{\mathrm{O}_{2}}$ は溶銑, スラグ 共に約 $5 \times 10^{-14} \mathrm{~atm}$ で等しかつた。これはスラグの $P_{\mathrm{O}_{2}}$ が溶銑より 1 析大きいといら高炉現場の結果 ${ }^{4)}$ と大 きく違ら点である. また後出の Fig. 7 に示すように長 寿命酸素センサーと消耗型センサーの結果は良く一致し た. 測定は作業時間の都合上 $6 \mathrm{~h}$ で打ち切つたが, 固体 電解質の外見は両センサーとも異常が見られなかつた. 長寿命センサーは実験室の試験では溶銑で $5 \mathrm{~h}$ 以上, ス ラグで $2 \mathrm{~h}$ 以上使用し得ることがわかつた. そこで次に 実操業中の高炉現場で $P_{\mathrm{O}_{2}}$ の連続測定を行つた。

\section{5. 高炉鋳床での $\boldsymbol{P}_{\mathrm{o}_{2}}$ の連続測定}

実験は川崎製鉄 (株)千葉製鉄所第 3 高炉と第 5 高炉で 行つた. センサーを長さ $3 \mathrm{~m}$ の鉄管に先端が約 $0.3 \mathrm{~m}$ 出 るように固定し，その鉄管を鉄製の台に固定した. 溶銑 用センサーは湯道のスキマーの後部にある湯道カバーの 空から溶銑に浸漬した. スラグ用センサーはスキマーの 前部で浸漬したが， $P_{\mathrm{O}_{2}}$ が黒鉛の然焼の影響を受ける可 能性が考えられたので流れに向かつて斜めに浸漬した. 浸漬深さはいずれも約 $0.1 \mathrm{~m}$ である.

リード線には補償銅線を組み込んだ 4 芯のゴム被覆ケ ーブルを用いた. 電池の起電力は $-1 \mathrm{~V}$ 以上発生するの で, 記録計へ入力する前に $1 \mathrm{~V}$ のハイアスをかけ起電力 の変化を拡大して記録した.

出銑前にセンサーを設置し, 湯道で予熱した. 出銑後 約 $10 \mathrm{~min}$, 溶銑の流量が安定した時点で溶銑用センサ 一を溶銑に浸漬して測定を開始した. 出銑中，溶銑面の 高さは変動するので, 随時センサーを上下してその浸漬 深さが一定になるように調整した. つぎにスラグがスキ マーから流出した後, 約 $10 \mathrm{~min}$ 後にスラグ用センサー
を浸漬した．そして，その出銑が止められた時点で両方 のセンサーを引き上げた，ただし，次の出銑が同一出銑 口から続けて行われる場合は，センサーをそのまま連続 して使らことを試みた。そその場合は，熱衝撃による破損 を避けるため固体電解質が溶銑から出ないようにした。 一方出銑止めの間は湯道のスラグが固まるので，スラグ 用センサーをスラグ上に引き上げておいたが，再浸漬す る時加熱されると熱衝撃で破損し，連続使用はできなか つた.

測定中，消耗型酸素センサーで時々 $P_{\mathrm{O}_{2}}$ を測定し，同 時に化学分析用の溶銑とスラグのサンプリングを行つ た。

\section{6. $\boldsymbol{P}_{\mathrm{O}_{2}}$ の連続測定結果}

Table 1 に長寿命酸素 センサーの使用結果を示す. Fig. 1 a) に示した構造の溶銑用センサーは M5 から M12 までの 8 本ですべて連続測定に成功した. Fig. 3 には M 5 から M11 までの $P_{\mathrm{O}_{2}}$ の測定結果を示す. $P_{\mathrm{O}_{2}}$ は出銑直後は低いが徐々に上昇して $10^{-14} \mathrm{~atm}$ 程度とな る. 溶銑温度は約 $1500^{\circ} \mathrm{C}$ であるがスラグが流出すると 少し上昇する傾向が見られた. Fig. 4 には連続して 3 回の出銑の間中測定した M12 の結果を示す.

M1 から M4 までは予備実験である.M1 と M2は標 準極に $\mathrm{Cr}-\mathrm{Cr}_{2} \mathrm{O}_{3}$ 混合粉末（重量比 $1: 9$ ）を用いたも ので，起電力は徐々に低下し安定しなかつた. M3 と 4 は溶銑との電気的接触にランタンクロマイト棒を用い たもので，溶銑に浸漬する際に熱衝撃で破損した. M10

Table 1. Life times of oxygen sensors for continuous measurements of $P_{\mathrm{O}_{2}}$ in pig iron and slag at blast furnaces.

\begin{tabular}{|c|c|c|c|c|c|c|}
\hline \multirow{2}{*}{ Date } & \multicolumn{3}{|c|}{ Sensor for pig iron } & \multicolumn{3}{|c|}{ Sensor for slag } \\
\hline & No. & Life time & note & No. & Life time & note \\
\hline '80. $7.11^{*}$ & & $\min$ & & $\mathrm{S} 2$ & $10 \mathrm{~min}$ & \\
\hline '81. 4.17 & & & & S 3 & 32 & 1 tap \\
\hline '83. 2.10 & & & & S 5 & 21 & 1 tap \\
\hline 83.6 .3 & $\begin{array}{l}\text { M5 } \\
\text { M6 }\end{array}$ & $\begin{array}{l}83 \\
82\end{array}$ & $\begin{array}{l}1 \text { tap } \\
1 \text { tap }\end{array}$ & S 7 & 15 & \\
\hline 83.9 .29 & $\begin{array}{l}\text { M7 } \\
\text { M8 }\end{array}$ & $\begin{array}{r}55 \\
118\end{array}$ & $\begin{array}{l}1 \text { tap } \\
1 \text { tap }\end{array}$ & $\begin{array}{l}\text { S } 11 \\
\text { S } 12 \\
\text { S } 13 \\
\text { S } 14 \\
\text { S } 15\end{array}$ & $\begin{array}{r}44 \\
22 \\
8 \\
5 \\
10\end{array}$ & 1 tap \\
\hline '83. 9.30 & $\begin{array}{l}\text { M9 } \\
\text { M10 } \\
\text { M11 }\end{array}$ & $\begin{array}{r}119 \\
79 \\
54\end{array}$ & $\begin{array}{l}1 \text { tap } \\
2 \text { taps } \\
0.5 \text { tap }\end{array}$ & $\begin{array}{l}\text { S } 16 \\
\text { S } 17 \\
\text { S } 18\end{array}$ & $\begin{array}{r}78 \\
8 \\
74 \\
\end{array}$ & $\begin{array}{l}1 \text { tap } \\
1 \text { tap }\end{array}$ \\
\hline '83.10.26 & M12 & 157 & 3 taps & $\begin{array}{l}\text { S } 19 \\
\text { S } 20 \\
\text { S } 21 \\
\text { S } 22\end{array}$ & $\begin{array}{l}10 \\
14 \\
10 \\
21\end{array}$ & \\
\hline
\end{tabular}

* This was tested at No. 3 Blast furnace and the other were at No. 5 BF in Chiba Works of Kawasaki Steel Corp. 


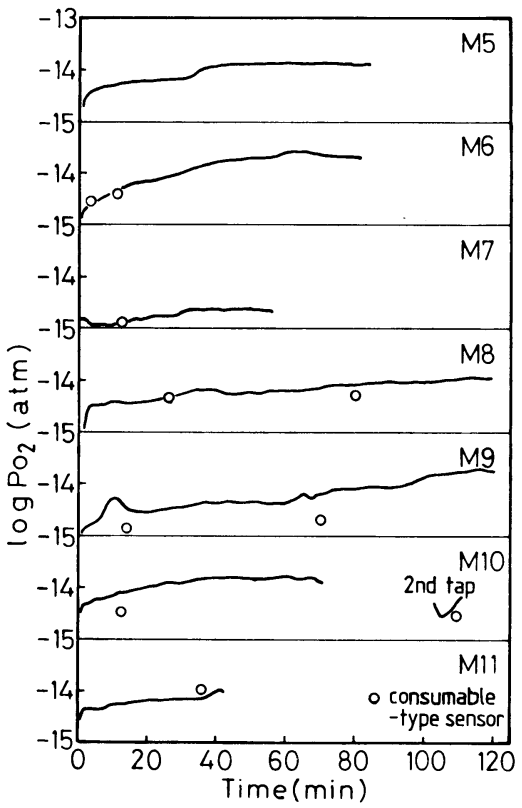

Fig. 3. $P_{\mathrm{O}_{2}}$ in pig iron continuously measured at No. 5 B.F..

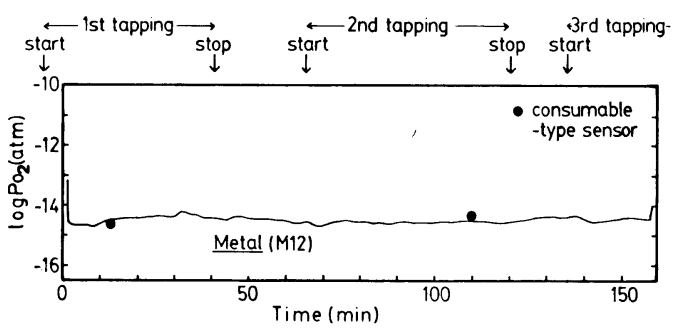

Fig. 4. $P_{\mathrm{O}_{2}}$ in pig iron continuously measured during 3 taps at No. 5 B.F..

では 1 回目の出銑止めの後, センサーを溶銑面上に引き 上げておいたために固体電解質にひびが入り，2回目の 出銑では数分で測定不可能になつた.

スラグ用長寿命酸素センサーは Fig. 1 b) に示す構 造のものをS 3 から S 22 まで 20 本試作し, そのらち 16 本が $5 \mathrm{~min}$ から $78 \mathrm{~min}$ 間連続して測定できた. Fig. 5 にスラグ中の $P_{\mathrm{O}_{2}}$ と温度の測定結果を示した. スラグの温度は約 $1500^{\circ} \mathrm{C}$ で溶銑とほとんど同じであ る. 温度は徐々に上昇し，それに応じて $P_{\mathrm{O} 2}$ も漸増して いる. Fig. 6 には比較的長時間の測定結果を示す. $P_{\mathrm{O}_{2}}$ は約 $10^{-13} \mathrm{~atm}$ で溶銑より 1 桁高いことがわかる.

短時間で測定が中断した原因は，スキマーのスラグ出 口の底が浅いため強いスラグ流に押されてセンサーの先 端が底に衝突し, 固体電解質が破損したためである. S 1 と S 2 では支持材に用いたアルミナ管が溶解した.

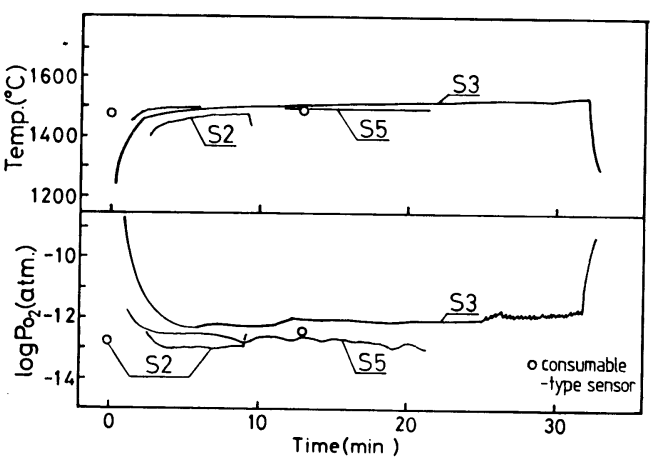

Fig. 5. $P_{\mathrm{O}_{2}}$ and temperature in slag continuously measured at No. 3 B.F. (S2) and at No. 5 B.F. (S3 and S5).

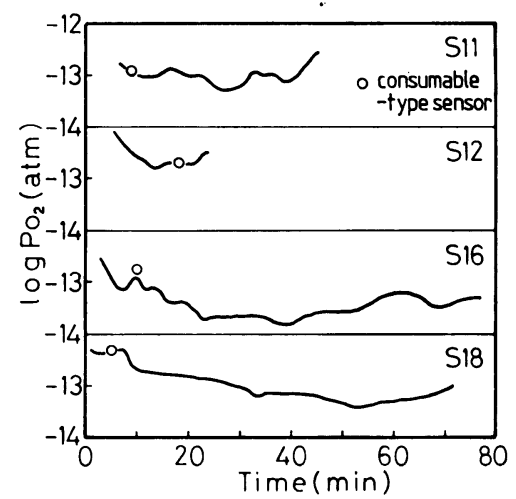

Fig. 6. $P_{\mathrm{O}_{2}}$ in slag continuously measured at No. 5 B.F..

\section{7. 考察}

\section{$7 \cdot 1$ 固体電解项の耐食性}

Photo. 1 に溶銑用とスラグ用センサーに使用した固 体電解質管の断面を示す. それぞれ $157 \mathrm{~min}$ と $44 \mathrm{~min}$ 間浸漬したものである.いずれる一端閉管には侵食され た形跡は認められない。スラグ用センサーの二重管の外 管の端が少し丸くなつている程度である.このように $\mathrm{ZrO}_{2} \cdot 9 \mathrm{~mol} \% \mathrm{MgO}$ 固溶体は溶銑およびスラグに対して 優れた耐食性を示す.

\section{2 標準楆物筫の選択}

酸素センサーを現場で使用する場合は，できるだけ構 造が簡単で交換が容易であることが望ましい，固体標準 極物質はこの点で有利である.しかし本実験で試みたよ らに $\mathrm{Cr}-\mathrm{Cr}_{2} \mathrm{O}_{3}$ 混合粉末を用いたセンサーは徐々に起 電力の低下をきたし信頼性に乏しかつた・そこで空気一白 金極を採用したが，溶銑やスラグ中の極低酸素分圧を測 定する場合は両極の $P_{\mathrm{O}_{2}}$ の差が大きくなるので次の点が 問題となる.すなわち固体電解質の部分電子伝導度が大 


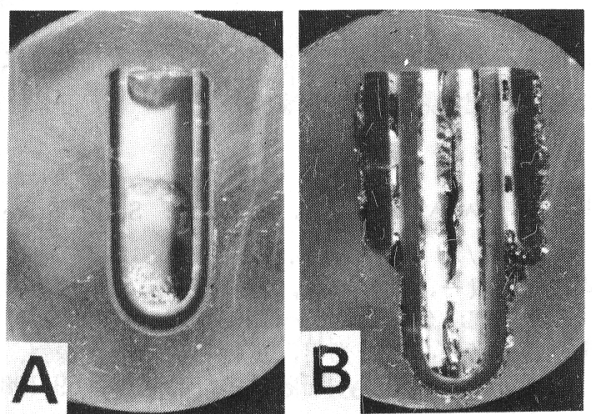

Photo. 1. Cross-sections of the solid electrolytes of $\mathrm{ZrO}_{2} .9 \mathrm{~mol} \% \mathrm{MgO}$ dipped in pig iron for 157 min and in slag for $44 \mathrm{~min}$.

きくなり，局部電池を構成して見かけ上酸素がスが流れ る. またクラックや気孔があつても酸素ガスが流れる. したがつて, 酸素濃度変化に対する緩衝能力が小さい電 極では分極を生じ起電力の低下をきたす. JANKE ${ }^{8\rangle}$ は, 固体電解質の壁を厚くして $P_{\mathrm{O}_{2}}$ 勾配を小さくするか, 平 衡酸素分圧の低い金属一金属酸化物系を標準極物質とし て用いることを提案している.

Fig. 7 に溶銑とスラグ中の $P_{\mathrm{O}_{2}}$ を, $\mathrm{Cr}-\mathrm{Cr}_{2} \mathrm{O}_{3}$ 混合 粉末を標準極物質とした消耗型酸素センサーと空気一白 金極を用いた長寿命酸素センサーで測定した場合につ いて比較した． $\mathrm{Cr}-\mathrm{Cr}_{2} \mathrm{O}_{3}$ 混合粉末の平衡酸素分压は $1500^{\circ} \mathrm{C}$ で $10^{-13} \mathrm{~atm}$ 程度である. 図中の $45^{\circ}$ の角度の 実線は理論的に一致する線であり，実測值はその周りに 対数にして $\pm 20 \%$ のばらつきで集まつている。これら

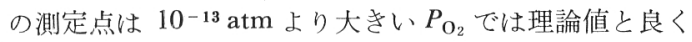
一致しているが，それより小さい $P_{\mathrm{O}_{2}}$ では長寿命酸素せ ソサーによる值の方がばらつきの範囲内であるが高い值 にずれている.

この誤差の原因として次のことが考觉られる5).

1 ）一般に， $50 \mathrm{ppm}$ 以下の溶鉄中の極低酸素濃度を 消耗型酸素センサーで測定する場合, 数 $\mathrm{ppm}$ のばらつ きが出る.これは酸素分圧にして対数で $20 \%$ 程度の誤 差に相当する. 本研究においても同様なばらつきが生じ ているが，この原因は現在，十分に解明されていない。

2 ) 固体電解質中に生ずる部分電子伝導の $P_{\mathrm{O}_{2}}$ に与光 る寄与が正確に補正されていない。この $P_{e}$ の值は測定 者により約 2 桁の差があり, 固体電解質の組成や焼結条 件に上つて異なると考光られる゙、. したがつて，個々の 固体電解質の $P_{e}$ の值を測定して括くことが望ましい.

3 ）消耗型酸素センサーの標準極に用いた $\mathrm{Cr}-\mathrm{Cr}_{2} \mathrm{O}_{3}$ 混合粉末により生ずる平衡酸素分圧之, 熱力学的に計算 で得られる平衡酸素分圧との䛊差. これは, 粉末の純

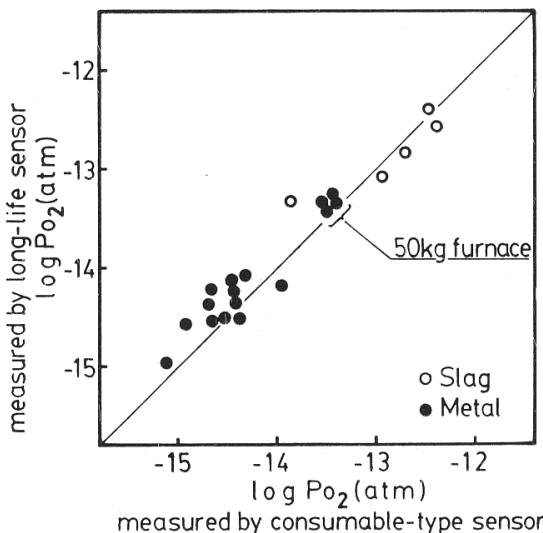

Fig. 7. Comparison of $P_{\mathrm{O}_{2}}$ in pig iron and slag measured by long-life sensors and by consumabletype sensors.

Table 2. Comparison of $P_{\mathrm{O}_{2}}$ and temperatures in pig iron and slag at tap hole and skimmer.

\begin{tabular}{cccccc}
\hline \multirow{2}{*}{ Place } & \multicolumn{2}{c}{ Pig iron } & & \multicolumn{2}{c}{ Slag } \\
\cline { 2 - 3 } \cline { 5 - 6 } \cline { 5 - 6 } Temp. $\left({ }^{\circ} \mathrm{C}\right)$ & $P_{\mathrm{O}_{2}(\mathrm{~atm})}$ & & Temp. $\left({ }^{\circ} \mathrm{C}\right)$ & $P_{\mathrm{O}_{2}}(\mathrm{~atm})$ \\
\hline \multirow{2}{*}{ Tap hole } & 1530 & $4.47 \times 10^{-15}$ & & 1546 & - \\
& 1537 & $5.37 \times 10^{-15}$ & & 1552 & - \\
\hline Skimmer & 1530 & $6.61 \times 10^{-15}$ & & 1540 & - \\
\hline Tap hole & 1497 & $3.02 \times 10^{-15}$ & & 1500 & - \\
\hline Skimmer & 1498 & - & & 1497 & - \\
\hline
\end{tabular}

度，形状，混合比および混合方法に依存すると同時に， $\mathrm{Cr}_{2} \mathrm{O}_{3}$ の標準生成自由エネルギーの值の誤差にも帰因す る.

以上述べたよらに，溶鉄中の極低酸素濃度を酸素セン サーにより精度良く測定するためには，まだ未解決の問 題が多い.

\section{3 出銑口とスキマーでの $\boldsymbol{P}_{\mathrm{O}_{2}}$ と温度の比較}

高炉内反応をモ二ターするたないは，直接センサーを 高炉内に入れて測定するのが望ましいが，商用炉では非 常に困難である。本研究ではスキマーで測定を行つたが 出銑口からスキマー屯で約 $20 \mathrm{~m}$ あり，湯道を溶銑と大 ラグが流れてくる間に空気と接触して $P_{\mathrm{O}_{2}}$ が上昇したり 温度が低下寸る可能性がある。そこで, 出銑口近傍とス キマーでの $P_{\mathrm{O}_{2}}$ および温度を測定した. 測定は消耗型酸 素センサーで行つた. その結果を. Table 2 に示す。溶 銑では出銑口とスキマーの間で, 温度と $P_{\mathrm{O}_{2}}$ 共に測定值 のばらつきの範囲内で変化がなかつた。一方, スラグで は出銑口での $P_{\mathrm{O}_{2}}$ の測定がすべて失敗したので $P_{\mathrm{O}_{2}}$ につ いては不明であるが，温度は両測定場所で汪とんど等し かつた. 失敗の原因はスラグ中に浮遊する粒鉄の付着に 
より，白金のリード線が切断したことによる。したがつ て, 高炉炉床部と出銑口近傍の溶銑とスラグの $P_{\mathrm{O}_{2}}$ と温 度に差がなければ，スキマーでの測定值は高炉炉床部の $P_{\mathrm{O}_{2}}$ と温度を表していることになる.

\section{8. 結言}

高炉から流出する溶銑と溶融スラグ中の $P_{\mathrm{O}_{2}}$ と温度を 連続して測定できる「長寿命酸素センサー」を試作し， 湯道のスキマーで測定を行つた.

活性で強い流れの溶銑と溶融スラグ中では, 固体電解 質として $\mathrm{ZrO}_{2} \cdot 9 \mathrm{~mol} \% \mathrm{MgO}$ が，その支持材として黒 鉛が有効であつた．標準極には空気一白金極を用いた。

溶銑用センサーは 3 回の出銑の間中連続して $157 \mathrm{~min}$ 間, スラグでは 1 回の出銑で $78 \mathrm{~min}$ 間の測定ができ た. 得られた $P_{\mathrm{O}_{2}}$ と温度は消耗型酸素センサーによる值 と良く一致した。

スキマーと出銑口近傍での溶銑と溶融スラグ中の $P_{\mathrm{O}_{2}}$ と温度はほとんど等しい。したがつて, スキマーでの測 定で高炉炬床部の $P_{\mathrm{O}_{2}}$ と温度をモニターできることがわ
かつた.

なお，本研究の一部は文部省科学研究費補助金によつ たことを付記し謝意を表します。

\section{文献}

1) $K$. Nagata and $K . S$. Goto: Solid State Ionics, 9/10 (1983), p. 1249

2 ) 成田貴一, 牧野武久, 松本 洋, 彦坂明秀, 勝田 順一郎: 鉄と鋼, 69 (1983), p. 1722

3 ) 春 富夫, 才野光男, 奥村和男, 阪口泰彦, 安野 元造, 赖谷暢男, 稲谷稔宏: 鉄と鋼, 69(1983), S 791

4 ) 永田和宏, 桘谷暢男, 角戸三男, 後藤和弘：鉄と 鋼, 68 (1982), p. 2271

5 ）永田和宏, 後藤和弘：鉄と鋼, 67 (1981), p. 1899

6 ) $W$. Pluschkell: Arch. Eisenhüttenwes., 46 (1975), p. 11

7 ) D. Janke and $W$. Fischer: Arch. Eisenhüttenwes., 46 (1975), p. 755

8 ) D. JANKE: Arch. Eisenhüttenwes., 54 (1983), p. 259

9 ) $M$. Inase, $E$. Ichise, $M$. Takeuchi and $T$. YAMASAKI: Trans. JIM., 25 (1984), p. 43 